\title{
TRANSUMANOS E PÓS-HUMANOS EM DEUSES DE PEDRA: A VALORIZAÇÃO DO CORPO PADRONIZADO NA DISTOPIA DE JEANETTE WINTERSON
}

\author{
Eduardo Marks de Marques* \\ Luana de Carvalho Krüger ${ }^{* *}$ \\ Universidade Federal de Pelotas
}

\begin{abstract}
Resumo: Em Deuses de Pedra (2012), escrito por Jeanette Winterson, há um espaço narrativo distópico do passado em que habitantes do planeta Orbus, praticamente destruído por intervenções humanas, vivem para as alterações genéticas e melhoramento estético dos seus corpos bonitos e jovens. Ao mesmo tempo, há um avanço tecnológico no desenvolvimento de robôs, sendo o mais representativo o robô sapiens, extremamente inteligente e belo e com características físicas humanas. Na narrativa há corpos distintos materialmente, no entanto, similares visualmente a partir de um ideal de padrão de beleza que incentiva a alteração dos corpos como um espaço de adaptação social. Nesse trabalho será analisado a relação entre corpo e tecnologia e qual a implicância dessas discussões para os estudos de transumanismo e pós-humanismo a partir dos corpos alterados das personagens e as consequências dessas alterações a partir da criação de um corpo ideal que promove uma ideia errônea de saúde perfeita através da interferência tecnológica.
\end{abstract}

Palavras-chave: Corpo. Tecnologia. Transumano. Pós-humano.

\section{Introdução}

Deuses de Pedra (2012), de Jeanette Winterson, é um romance distópico que apresenta o planeta Orbus, um lugar em vias de destruição, no qual os habitantes em breve não conseguirão sobreviver sob nenhuma circunstância. Os cientistas estão à procura de um outro espaço e investigam o planeta Azul, um lugar ainda inabitado por humanos e que precisa ser investigado e explorado. $\mathrm{O}$ aquecimento global e a poluição estão atingindo níveis

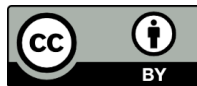

Esta obra está licenciada sob uma Creative Commons - Atribuição 4.0

\footnotetext{
* Professor Associado da Universidade Federal de Pelotas, doutor em Australian Literature and Cultural History - University of Queensland (2007) e pós-doutorado em Estudos Literários, ênfase em Teoria Literária pela Universidade Federal de Minas Gerais (2014). E-mail: eduardo.marks@mandic.com.br.

** Graduada em Letras Português/Inglês e respectivas literaturas em 2017 pela Universidade Federal de Pelotas. Mestranda do Programa de Pós-graduação em Letras - Literatura Comparada da Universidade Federal de Pelotas. Bolsista CAPES/FAPERGS. E-mail: luana-kruger@hotmail.com.
} 
bastante altos e comprometendo a vida e o bem-estar dos habitantes do planeta Orbus que estão divididos entre três espaços geográficos: a cidade tecnológica e os lugares mais afastados, o Califado e o Pacto Sino Mosco, sendo o primeiro um lugar em que os moradores vivem com bons recursos e maior qualidade de vida e os outros espaços onde há um descaso do governo, a Potência Central.

Apesar dos problemas climáticos e do caos ambiental em que o planeta se encontra, observa-se que estas não são as maiores preocupações dos habitantes que, com os avanços tecnológicos disponíveis, podem fazer várias alterações em seus corpos. A maioria dos habitantes no planeta Orbus são belos e jovens em função da adaptação genética, o que permite que eles não envelheçam. Há controle e vigília constantes da população e tais mudanças estéticas são naturalizadas, de modo que há uma expressiva padronização dos corpos que gerou algumas consequências como a falta de libido de alguns pelos seus parceiros e/ou semelhantes, a ponto de procurarem prazer sexual a partir de corpos distintos como crianças e corpos fora do padrão ou com alguma anomalia.

Tais alterações nos corpos poderiam ser compreendidas, à primeira vista, como algo positivo que melhoraria o desempenho desses indivíduos. No entanto, ao observar que a tecnologia está a serviço de uma padronização estética pode-se começar a refletir acerca dessa interferência, pois "[...] não se trata de qualquer corpo, trata-se de um corpo manipulado, fabricado, reconstruído, que apresenta a 'beleza e a saúde perfeita' como metas a serem alcançadas" (TRINCA, 2008, p. 04). O corpo deixa de ser um espaço de manifestação individual e passa a ser uma forma de imposição social, em que o sujeito só é sujeito a partir da semelhança com o outro, a qual é levada ao extremo quando pensa-se não somente em características físicas que nos agrupam em uma mesma espécie, mas que selecionam traços estéticos e que nos limitam ao que é socialmente belo.

Essa relação entre tecnologia e padronização avança também para as máquinas. $\mathrm{Na}$ narrativa há diversos tipos de robôs: aqueles que servem para trabalhos domésticos, outros que trabalham para o governo como fiscais e, ainda, os robôs sapiens que são extremamente inteligentes, pois são alimentados pelos humanos com informações históricas e atuais. Os robôs sapiens são muito belos e atraentes e seus corpos se assemelham com os corpos dos habitantes de Orbus, eles são "[a] primeira criatura artificial que parece humana e age como humana, e que é capaz de evoluir como um ser humano [...]” (WINTERSON, 2012, p. 26). Há aqui espaços conflitantes, pois a funcionalidade da máquina deixa de ser somente a produtividade pela inteligência e função a ser desempenhada, mas ganha também o fator 
estético, que a coloca em outro ângulo de visão em que o corpo adquire valor, da mesma forma que os corpos das outras personagens da narrativa. Diferentemente dos robôs sapiens, os outros robôs ainda possuem características físicas de acordo com a sua funcionalidade.

Nesse trabalho será discutida a importância do corpo dentro da narrativa para compreender o papel desempenhado pelas personagens, observando a partir dos estudos acerca do transumanismo e pós-humanismo se o corpo seria somente uma consequência dessas transformações ou se de fato desempenha um papel relevante na narrativa.

\section{Humanos, transumanos ou outra espécie: quem são os habitantes de orbus?}

$\mathrm{Na}$ distopia de Jeanette Winterson há uma história que apresenta um passado primórdio. Antes de qualquer existência de vida humana no planeta Azul, planeta desbravado no primeiro capítulo da obra, há o planeta Orbus. Orbus já não possui recursos naturais necessários para a existência de humanos, pois foi quase que completamente destruídos por grandes empresas, bem como pelos próprios habitantes. O planeta Orbus está chegando ao fim pois, “[...] escolhemos [a população de Orbus] alguns caminhos errados. Cometemos alguns erros. Reduzimos os recursos naturais à nossa disposição e temos uma população crescente que de forma alguma é favorável à maneira com a qual nosso mundo, como um todo, deve partilhar os recursos que restam" (WINTERSON, 2012, p. 11). Resta uma esperança nesse novo planeta, ainda muito desconhecido, mas que traz outras fontes de recursos naturais já esgotadas em Orbus.

A importância dessas discussões apresentadas no romance é central pois elas funcionam como um "aviso de incêndio, o qual, como todo recurso de emergência, busca chamar a atenção para que o acontecimento perigoso seja controlado, e seus efeitos, embora já em curso, sejam inibidos." (HILÁRIO, 2013, p. 202, grifos do autor). Os romances distópicos apresentam esses questionamentos políticos, que permitem observar também o que estamos vivendo. No entanto, há aqui outros aspectos relevantes que esse romance aponta, frutos de um sistema capitalista que força os indivíduos a uma adaptação excessiva, que reflete diretamente nos seus corpos.

\footnotetext{
O corpo humano, orgânico, não é mais autossustentável enquanto essência de humanidade. Em outras palavras: o capitalismo tecnológico, através da construção e manutenção do desejo, transformou-nos em ciborgues, seres cuja existência orgânica é falha e deve ser melhorada (e, se possível, prolongada) através da tecnologia. (MARKS DE MARQUES, 2014, p. 18).
}

Pode-se questionar acerca da população de Orbus e de que maneira pode-se definilos para a presente análise. Uma possível indagação seria se os habitantes de Orbus poderiam 
ser chamados de humanos, mesmo não habitando o Planeta Terra. Em um primeiro momento, poderíamos definir humanos como uma espécie animal racional. De todas as espécies existentes e, inclusive, extintas seriam os humanos (até então) os detentores de um conhecimento amplo em relação as outras espécies e que dominam a língua de forma superior. Tais conceitos são bastante básicos, no entanto, extremamente relevantes, pois é a partir deles que se consegue construir outras definições. Ao se pensar em seres humanos, não se pode deixar de associar a evolução da espécie dos primatas, sendo o Homo sapiens a mais evoluída de todas e a qual nos encontramos ${ }^{1}$. Observar essas evoluções é considerar que estamos estanques e não há mais formas de melhoramento, pois "[o] ser humano está rodeado de ambiguidade e complicação. Ser humano é procurar definir o que é ser humano. É talvez a missão essencial. [...] o ser humano não é um ser estático, mas se define de novo no decorrer de suas experiências históricas.” (MAZLISH, 2009, p. 63, tradução nossa) ${ }^{2}$. Malzlish ainda fala que outros conceitos como humanidade, civilização, humanidades e humanitarismo são relevantes para a compreensão do significado de ser humano e nos lembra que muitos desses termos estão diretamente ligados a questões históricas e culturais, principalmente de regiões com maior concentração de poder e que, portanto, definem com maior relevância alguns aspectos desse conceito. (MAZLISH, 2009, p. 74).

Outro aspecto relevante é pensar na origem da espécie humana, que até então é compreendida a partir do planeta Terra. Acredita-se que só haja vida humana e seres humanos porque há o planeta Terra; ou seja, as condições do planeta criaram a possibilidade de existência de muitas espécies, inclusive a nossa. A narrativa mostra um universo cíclico e embora não se saiba o que aconteceu anteriormente à Orbus, o leitor sabe o que está acontecendo no planeta Terra/Azul. Ainda que se trate de uma obra de ficção, não se pode descartar a verossimilhança que o romance apresenta e que é parte importante para a construção de uma distopia que, nesse caso, apresenta um planeta quase destruído e o Planeta Azul que "[...]oferece a oportunidade de fazer coisas de modo diferente. Tivemos muitos êxitos brilhantes aqui em Orbus... bem, nós representamos o êxito de nosso universo, não é verdade? Isto é, nenhum outro planeta abriga vida humana." (WINTERSON, 2012, p. 11). Orbus torna-se muito semelhante ao que se compreende como um planeta possível para existência da espécie humana, reforçado na própria narrativa.

\footnotetext{
${ }^{1}$ Sabe-se que há divergências entre Homo sapiens e Homo sapiens sapiens, optamos por não entrar nessa discussão nesse momento e utilizar a primeira.

${ }^{2}$ Do original: The human being is surrounded in ambiguity and complication. To be human is to seek to define what being human means. It is perhaps the essential quest. In my view, the human is not a static being, but it defines itself afresh in the course of its historical experiences.
} 
Nessa mesma perspectiva, a narrativa permite observar que as características dos habitantes de Orbus são também características semelhantes aos humanos, por exemplo, a compreensão das linguagens artísticas e preservação da arte. Essas são questões fundamentais para a definição de humano, pois nenhuma outra espécie consegue realizar e estabelecer uma relação de significado com diferentes formas de manifestação artística como o Homo sapiens. Um desses exemplos é através do comandante da espaçonave, o senhor Handsome, que leva alguns habitantes de Orbus para o Planeta Azul. Handsome gosta de história e poesia, ao conversarem sobre os planetas, ele diz: "Vou dizer o que eu acho [...] e vou dizer da maneira que qualquer marinheiro diria, por meio de uma história, uma história antiga que veio das naves espaciais" (WINTERSON, 2012, p. 81).

Outro aspecto é que há muitas semelhanças entre os corpos dessas personagens e os nossos corpos, não somente as questões mais fisicamente estruturais, mas também os padrões de beleza heteronormativo como, por exemplo, homens fortes e grisalhos, mulheres magras, no entanto, com curvas. Ainda que alguns padrões possam mudar com o passar dos anos, a decisão por deixá-los similares aos padrões da nossa sociedade revelam um interesse em colocar a verossimilhança como ponto alvo da narrativa, como no trecho:

[...] O apelido que nos deram foi "Dinastia do DNA", depois que a primeira geração de seres humanos reformou o código genético com êxito. A idade é uma falha da informação. $\mathrm{O}$ corpo perde sua fluência. As estações de comando já não se ligam com as dos satélites. Os canais de comunicação se deterioram. O corpo é projetado para reparar-se e renorvar-se sozinho; a maioria das células tem apenas um terço da nossa idade cronológica, mas o DNA mitocondrial tem a nossa idade real, e sempre acumulou mutações e distorções mais rapidamente do que o DNA do núcleo." (WINTERSON, 2012, p. 18).

Para além das características visuais desses corpos, há características genéticas que são muito semelhantes as nossas características, o que também aproxima os habitantes de Orbus da mesma compreensão de humanos existente na nossa sociedade. Durante todo o romance as personagens referem-se a elas mesmas como humanos e/ou seres humanos, tal definição poderia ser facilmente questionada quando pensa-se que tal substantivo, não passaria de uma palavra que poderia caracterizar outro corpo, no entanto, no trecho a seguir, enquanto a narradora-personagem Billie fala sobre os robôs sapiens, identifica-se uma comparação relevante para a presente análise: "São [os robôs sapiens] tão avançados em relação aos robôs-guardas quanto nós em relação ao homem de Neandertal." (WINTERSON, 2012, p. 25), ou seja, uma espécie humana extinta. Ao colocar o "nós" como comparação a uma espécie extinta e essa espécie ser comprovada cientificamente uma espécie humana com características similares ao Homo sapiens, pode-se compreender os habitantes de Orbus como 
a mesma espécie humana.

Por fim, para definições de humano, há a robô sapiens, Spike, que já pelo nome possui semelhanças com a espécie humana, como possui um corpo e uma beleza que é reconhecida e tida como atraente para os habitantes de Orbus. A semelhança corporal é importante, pois embora eles dominem a mesma língua, é o corpo o que mais impressiona. Além disso, os robôs sapiens foram criados para evoluir, o que se assemelha aos humanos, pois esse seria o objetivo e o diferencial da espécie. Pode-se, a partir desses pontos de argumentação, definir os habitantes de Orbus como humanos, assim como a nossa própria existência. A partir desse momento, começa-se a discutir as transformações que os habitantes de Orbus estão passando, pois eles recebem bastante influência midiática acerca dos corpos e da perfeição desses corpos, fato que é extremamente presente dentro da nossa sociedade.

O século XXI assistiu a uma crescente valorização do corpo suscitando uma série de reflexões acerca de aspectos epistemológicos inter-relacionais como: corpo-mente, corpo-saúde, corpo-aprendizagem cognitiva, corpo-comunicação, corpo-sujeito, corpo-consumo-mercadológico e corpo contemporâneo. Esse fenômeno emergente é atribuído à grande força da mídia e ao surgimento de uma cultura de consumo como característica da sociedade contemporânea. (LIMA, 2013, p. 02).

Embora não seja possível identificar precisamente o período em que se passa a narrativa, sabe-se que as semelhanças com o nosso momento histórico são grandiosas. Não seria diferente compreender que esses corpos recebem influência desse mercado de consumo que permite alterações expressivas como uma forma de adaptação. $\mathrm{O}$ uso do corpo na publicidade é inevitável para se pensar em um padrão de beleza e/ou um ideal a ser atingido com o uso de específicos recursos estéticos. A padronização e venda de um corpo ideal (ainda que variável em diferentes culturas) é fortemente colocada em evidência, utilizando, em muitos casos, o discurso da saúde atrelado ao da boa aparência e da boa forma como condição sine qua non para um sucesso pessoal, profissional e, inclusive, afetivo.

Tais discussões acerca da publicidade refletem de maneira considerável o que vem sendo estudado nas áreas de saúde e estética, essas estratégias de venda estão sendo discutidas como uma manipulação dos indivíduos que acabam comprando o produto como forma de obter um resultado quase impossível e improvável de padronização física e estética dos corpos. Aos que não se encaixam nesse padrão e que não procuram adequar-se a ele, ou ainda, que procuram subvertê-lo, cabe um arsenal de argumentos, que têm como objetivo principal mostrar que tal discurso é, na maioria dos casos, um discurso do consumo que não leva o sujeito a ser melhor, mas sim, a consumir um produto específico. Em um diálogo entre Spike e Billie temos: 
- Todos os seres humanos na Potência Central foram aperfeiçoados, adaptados e fixados geneticamente e tiveram o DNA mapeado. Alguns foram clonados. A maioria nasceu fora do ventre. Os seres humanos de hoje não são os mesmos de há cem anos. Então, o que é um ser humano?

- Seja o que for, não é um robô - eu disse. [Billie]

$[\ldots]$

Spike não se dava por vencida.

- Mas quero saber como você está fazendo a distinção, mesmo sem engenharia biológica, o corpo humano está em constante estado de mutação. O que você é hoje não é o mesmo que será em alguns dias, meses, anos. Todo o seu esqueleto se refaz inteiramente a cada dez anos, seus glóbulos vermelhos se refazem a cada 120 dias, sua pele a cada duas semanas. (WINTERSON, 2012, p. 95).

O questionamento de Spike parece ser pertinente, pois as personagens encontram-se frente a tantas transformações que já não caberia mais defini-las como humanos, as interferências genéticas são grandiosas e já alteraram suas capacidades humanas, como a do envelhecimento. Percebe-se na narrativa o que também acontece atualmente na nossa sociedade em que cirurgias plásticas e/ou uso de produtos estéticos já não são exclusivamente para reparos na saúde e as transformações são constantes desde as biológicas, até as artificiais. Há uma relação dupla com os corpos, pois ao passo que se necessita de suas funções e não se pode perdê-lo, o corpo é alterado a todo instante para ser deixado, na maioria das vezes, visivelmente melhor.

Desse modo, nossa sociedade tanto cultua o corpo como não cessa de desprezá-lo, comercializá-lo e coisificá-lo. O corpo reina e padece diariamente. Propagam-se as "deficiências" e os limites corporais, desvalorizam-se as singularidades e potencialidades dos sujeitos e os tornam desnecessários, descartáveis, sem sentido, e, simultaneamente, o aclamam, fazendo do corpo o mais sublime objeto de adoração. (TRINCA, 2008, p. 03).

É o que se nota quando os corpos diferentes são colocados em um outro patamar que, na narrativa, se dividem em dois grandes universos: o sexualizado e descartado. Ao mesmo tempo em que a obra apresenta corpos excêntricos e que começam a atrair os habitantes de Orbus, pois muitos perderam o interesse sexual pelos que passaram pela adaptação genética (todos são muito semelhantes), há também aqueles que sofreram e/ou nasceram com alguma deformidade e são excluídos, colocados em um campo radioativo para morrer. Há corpos alterados para atrair e corpos que nasceram com deformidades e que são descartados.

Foi quando os vi, atravessando a escuridão nos limites externos da Playa. Vinham engatinhando, apoiando-se em muletas feitas com galhos podres da floresta, esfarrapados, maltrapilhos, com chagas e úlceras abertas, sangrando, desdentados, cegos, mudos, aleijados, mutantes, mas vivos - a definição do que é humano. Almas?

Moravam na Floresta Morta. Eram destroços causados pelas bombas, as vítimas colaterais, os mortos na terra, de sangue envenenado, pulmões perfurados, gânglios inchados, pele cor de papel sujo, olhos amarelados, corpos lacerados, manchados 
como sapos, como pústulas de onde saia uma gosma espessa, rosto mucosos, calvos, com cicatrizes, amedrontados, vivos, humanos. (WINTERSON, 2012, p. 270).

Billie compreende esses indivíduos jogados nessa floresta como humanos, e talvez para ela - uma personagem transgressora em relação as mudanças corporais, pois consegue ver o excesso demasiado delas - os únicos humanos da narrativa. No entanto, socialmente não o é: os únicos corpos que são valorizados são aqueles que são considerados esteticamente perfeitos. Esses corpos considerados perfeitos só o são por terem passado por muitas alterações, ao passo que os corpos sem interferência são imperfeitos, fora do padrão que, na narrativa, é extremamente fechado. As interferências tecnológicas são fundamentais, pode-se dizer imprescindíveis na narrativa. Observa-se que a tecnologia desempenha um papel fundamental para a manutenção desses corpos considerados esteticamente imperfeitos, ou ainda dos corpos que necessitam da intervenção tecnológica para obterem um melhor desempenho.

A ênfase na precariedade da carne, na imperfeição, na falta de resistência, no
envelhecimento progressivo e na morte como ameaça constante alimentam o
imaginário social referente ao descrédito para com o corpo real e amparam diversas
pesquisas científicas e numerosas práticas cujo intuito é remediar as deficiências do
orgânico por meio de procedimentos técnicos e métodos de gestão e controle.
(TRINCA, 2008, p. 03).

Para além do que Trinca diz, em Deuses de Pedra as interferências tecnológicas avançam mais que um mero melhoramento do corpo, elas revertem o envelhecimento dos corpos e colocam os indivíduos, ainda que mortais, dentro de um padrão de não envelhecimento que abre margem para uma ilusão de manutenção de vida. Observa-se isso quando a idade dos indivíduos não é mais celebrada, somente o aniversário de manutenção genética, “[...] [a]gora os aniversários não são importantes, porque marcam o transcurso dos anos, e para nós os anos não passam mais como acontecia antes. O dia G é o dia da adaptação genética de cada um. É o dia que vale a pena comemorar." (WINTERSON, 2012, p. 27). Esses corpos sofrem grandiosas alterações, que podem ser perigosas, pois “[...] [a] reversão genética causa estranhos efeitos ao corpo. Da última vez que foi praticada, não foi possível deter o processo e a mulher foi ficando cada vez mais jovem até estacionar como um bebê de 6 meses e 1,80m de altura". (WINTERSON, 2012, p. 29). Todavia, para a maioria dos habitantes de Orbus isso não é relevante e o que mais importa é as transformações que eles querem fazer, como uma personagem que insiste em adaptar o seu corpo ao de uma criança de 12 anos para que o marido volte a sentir atração por ela diz: "Posso mudar mais tarde, se não der certo." (WINTERSON, 2012, p. 28). 
Acredita-se que os habitantes de Orbus estão em um constante processo de transformação desses corpos que caminham para que eles cada vez mais tenham autonomia. Seriam eles o que identifica-se como transumanos que podem ser definidos como uma nova etapa da nossa própria espécie em que "[a] humanidade seria então capaz de evoluir a si mesma através da tecnologia, e tal evolução estaria a cargo de seu desejo e não de uma ordem divina ou de processos naturais aleatórios" (MARKS DE MARQUES; PEREIRA, 2017, p. 122), e chegando ao pós-humano, onde haverá "[p]essoas com capacidade física, intelectual e psicológica sem precedentes, auto programadas, indivíduos auto constituintes, potencialmente imortais e ilimitados (BRODERICK, 2013, p. 430, tradução nossa) ${ }^{3}$. Considera-se tanto o caráter 'humano' dessas personagens, como também o caráter 'transumano', pois diante do momento da narrativa, há muitas modificações desses indivíduos, principalmente de seus corpos em que toda 'evolução' ocorre através dos recursos tecnológicos disponíveis para as personagens.

Tais processos evolutivos podem ser compreendidos a partir de duas perspectivas: a evolução pela mente e pelo corpo. Tratando de avanços em relação a mente, pensa-se em algo que preserve o humano a partir da mente, seja aqui compreendido como o transplante de cérebro ou ainda outras formas de preservação das faculdades mentais dos indivíduos. Há também associações entre mente e alma que se direcionam mais para uma transcendência do ser e aspectos religiosos. ${ }^{4}$ Outro seria através da conservação do corpo, a partir da manutenção dos corpos, biologicamente imperfeitos, que é pensada há muito tempo, um exemplo é a criogenia ${ }^{5}$. Essas duas perspectivas se opõem e embora não haja uma resposta irrefutável para esse questionamento, acredita-se que as duas têm pontos importantes que devem ser considerados dependendo da linha teórica a ser seguida. Todavia, ainda que em um primeiro momento o corpo possa ser o mais objetificado e descartado, é também ele que mais passa por processos de adaptação que permite afirmar que o corpo tem papel fundamental para a compreensão de humano, o que leva diretamente a compreensão de que o é também para a definição de transumanos e pós-humanos. Um exemplo bem claro na narrativa são as adaptações genéticas, em que através de recursos tecnológicos há ainda um mercado que envolve todas essas transformações dos humanos, de modo que inclusive o alimento vendido para as personagens é produzido por uma empresa que os vende como naturais, embora não

\footnotetext{
${ }^{3}$ Do original: Persons of unprecedented physical, intellectual, and psychological capacity, self-programming, self-constituting, potentially immortal, unlimited individuals.

${ }_{5}^{4}$ Deter-nos-emos a ideia de mente a partir de uma perspectiva biológica.

${ }^{5}$ Processo que permite conservar os corpos através de congelamento para uma possível ressureição futura, ainda sem perspectiva de acontecer.
} 
tenham nenhuma comprovação dessa afirmativa. Ao mesmo tempo as comidas orgânicas são rejeitadas e eles se alimentam a partir de uma dieta que chamam de nutrição natural, ou seja, “[...] somente os produtos sintéticos mais caros, com equilíbrio de proteínas e minerais, para manter a saúde perfeita.” (WINTERSON, 2012, p. 67).

Esses dois pontos são importantes, pois evidenciam o quanto o corpo é relevante quando se pensa na evolução dos indivíduos. Ainda que os estudos transumanistas e póshumanistas caminhem para a ideia de imortalidade, e um desses aspectos seria a manutenção da mente, não parece ser este o foco de manutenção e prioridade para os avanços tecnológicos e também para o nicho de mercado que se desenvolve diante de produtos estéticos. A busca pelo resultado que é visível a olho nu, parece ser mais relevante do que aqueles que se colocam frente a algo que somente poderia ser notado pelo próprio indivíduo.

Segundo Lima (2013, p. 3),

[v]alorizar o corpo significou ampliar o seu conceito, compreendendo-o para além de um mero espaço físico ocupado por um conjunto de órgãos, pois passa a ser nele o lugar em que se dá, se realiza e se manifesta não só as suas aptidões e contingências físicas, mas também e sobretudo o conjunto complexo de reciprocidade e inter-relações entre as emoções, a sexualidade, sentimentos, os pensamentos e os desejos humanos, tornando assim a noção ou mesmo o conceito de "corpo" em algo eminentemente rico e complexo.

Todos desejam ser bonitos e ter uma boa aparência. Tal desejo é mais forte, inclusive, do que a qualidade de vida das personagens. Elas não parecem se importar se com os problemas que Orbus apresenta e que os impedirão de viver lá, eles querem saciar desejos momentâneos que os qualificam na sociedade e os permitem um status social. A população de Orbus, com exceção de algumas personagens, são transumanas e o que importa e gera lucro não são os estudos que permitem ao indivíduo uma maior capacidade intelectual, mas o que permite um melhor corpo, mais adaptado, mais adequado a demanda da indústria de cosméticos e farmacêutica, além das demandas estéticas via cirurgias.

A narrativa evidencia que o belo é o que está dentro do padrão e que tal padrão é definido por grandes empresas que lançam novos desejos para os compradores que assumem o uso desses produtos como uma forma de se adaptarem. Há uma ênfase no mercado capitalista que ao se preocupar sempre com o retorno econômico, acaba por insistir em novos produtos que atraiam a população. Na narrativa esse mercado é representado pela MAIS, uma empresa que domina tanto o campo estético, quando outras áreas e que visa o lucro diante de qualquer produto e/ou ação. 
[...] A MAIS é uma empresa comercial e continuaremos a fazer o que sabemos fazer bem - mas acho que já demonstramos que dentre todas organizações poderosas, governamentais ou não governamentais, a MAIS é a única que existe e foi capaz de produzir resultados Pós-3G [fala do presidente da MAIS na televisão].

Abaixo [Billie] o volume e me sirvo de um pouco mais de do uísque MAIS com gelo. (A MAIS é proprietária da destilaria do estado.) O que ele disse é verdade: milhões de pessoas concordarão e se servirão de mais um drinque.

A MAIS tem sido a mais agressiva das empresas mundiais no mercado, desrespeitando as regulamentações e aumentando as emissões de carbono. Seus advogados extremamente bem pagos combatem os acordos antipoluição, as tarifas e os subsídios, tudo o que pudesse parecer um freio aos gastos de consumo. (WINTERSON, 2012, p. 188-189)

Não há uma preocupação da empresa com os recursos naturais, muito menos com as consequências de tantos avanços tecnológicos para alteração nos corpos. Para além disso, não há espaços para as individualidades e tudo que foge do padrão estético, caminha para o excêntrico. Através do discurso da beleza, ganha-se quase as mesmas identidades corporais e visuais, o que acaba gerando conflito, pois é a partir da padronização que se pode identificar os desvios das regras e os desejos criminosos justificados pela própria padronização dos corpos, como a pedofilia:

[...] O que quero dizer é que fazer com que todos ficássemos jovens e bonitos também nos fez mortalmente entediados com o sexo. Todos os homens têm pênis enormes. Todas as mulheres são apertadinhas entre as pernas, como ostras, e infladas como boias na parte de cima do corpo. Os queixos são quadrados, a pele é morena, os músculos rijos e ninguém fica com tesão.

$[\ldots]$

Por isso, o sexo sensual agora é com gente deformada e com crianças. Quem quiser trabalhar no comércio do sexo tem de modificar a forma e o tamanho do corpo. As mulheres gigantes têm grande procura. Os grotescos ganham bom dinheiro. As crianças de menos de 10 anos são chamadas de "novilhos" nessa atividade. (WINTERSON, 2012, p. 32-33, grifos da autora)

Dentro de um espaço distópico tal padronização torna-se interessante como um próprio alerta para as propagandas de empoderamento e liberdade dos corpos que mais faz utilizar de um discurso político para adquirir um público que acaba sendo induzido a um modo de agir diante de uma liberdade de decisão mascarada. O mais considerável para a compreensão de humano (o corpo ou a mente) é ainda incerto, no entanto, pode-se afirmar que o corpo é cientificamente considerado imperfeito e:

[e]mbora a ciência tenha nos fornecido os meios para transformar nossos corpos, não pode nos dar nenhuma orientação sobre como esses meios devem ser empregados [...] É por isso que, para muitos, a remodelação cirúrgica de seus corpos se torna um processo sem fim, pois eles se envolvem em uma busca impossível de uma identidade que está para sempre além do alcance. (NEGRIM, 2008, p. 92, tradução 
nossa $)^{6}$.

Cabe agora, procurar compreender até que ponto as interferências da tecnologia devem ter um limite e aonde os estudos acerca do pós-humanismo nos levam em relação as discussões da manutenção dos corpos. Por hora, na narrativa, o corpo humano fica entre o jogo de importância e uso desenfreado, em que os limites estéticos podem ser demasiados, no entanto, sua funcionalidade é mantida através de recursos que garantem ainda que de maneira equivocada uma vida melhor e mais autônoma para os humanos de Orbus.

\section{Robô-sapiens: a essência do corpo humano}

Como já citado acima, o transumano seria um momento de transformação para o póshumano em que todas as capacidades destes, sejam físicas e/ou mentais, poderiam ser controladas pelo próprio indivíduo. Os avanços tecnológicos já permitem muitas interferências nos corpos, que surgem justamente para um melhoramento das nossas imperfeições. Pode-se dizer que:

[...] o transhumanismo compartilha alguns valores pós-modernistas, como a necessidade de mudanças, a reavaliação do conhecimento, o reconhecimento de identidades múltiplas e a oposição a classificações acentuadas do que os seres humanos e a humanidade deveriam ser. No entanto, o transumanismo não descarta a totalidade do passado por causa de algumas ideias equivocadas. O humanismo e o conhecimento científico provaram sua qualidade e valor. Deste modo, o transumanismo procura uma transmodernidade ou hipermodernismo em vez de argumentar explicitamente contra o modernismo. (MORE, 2013, p. 02, tradução nossa) $)^{7}$.

Compreende-se que o transumanismo é um processo, uma forma de ver a humanidade, sem descartá-la e/ou rejeitá-la completamente, ao mesmo tempo em que caminha para o pós-humanismo que compreende o pós-humano como:

[...] a "pessoa" possuidora de capacidades físicas e intelectuais sem precedentes, a entidade possuidora dos princípios de sua autoformação e um caráter transcendente, porque potencialmente imortal, é pós-humana, seja ciborgue ou máquina de inteligência artificial. Quem atinge esse ponto não mais pode ser chamado de humano, e é para se chegar até o mesmo converter-se em pós-humanos que muitos crentes na tecnologia vêm se organizando desde o final do século XX. (RÜDIGER, 2008, p. 142).

\footnotetext{
${ }^{6}$ Do original: While science has provided us with the means by which to transform our bodies, it is unable to give us any guidance as to how these means should be employed [...] That is why, for many, the surgical refashioning of their bodies becomes a never-ending process as they engage in an impossible search for an identity that is forever beyond reach.

${ }^{7}$ Do original: (...) transhumanism shares some postmodernist values, such as a need for change, reevaluating knowledge, recognition of multiple identities, and opposition to sharp classifications of what humans and humanity ought to be. Nevertheless, transhumanism does not throw out the entirety of the past because of a few mistaken ideas. Humanism and scientific knowledge have proven their quality and value. In this way, transhumanism seeks a transmodernity or hypermodernism rather than arguing explicitly against modernism.
}

Anu. Lit., Florianópolis, v. 23, n. 1, p. 154-173, 2018. ISSNe 2175-7917 
O pós-humano seria o ponto mais alto das possíveis transformações, o caráter divino passaria para o próprio homem que conseguiria controlar o seu corpo, além de ter maior percepção de tudo a sua volta. Um controle não só da mente, mas também do seu próprio corpo, seja com recursos da robótica ou totalmente maquinizado.

O pós-humano, na narrativa, é identificado na robô sapiens, não como o exemplo de pós-humana, pois ela não tem origem humana, mas por conter traços de pós-humanidade que são relevantes para a compreensão de um pós-humano. Embora Spike seja uma robô, ou seja, uma máquina programada para agir de formas específicas, sendo uma delas a evolução, observa-se que se um robô é programado para a evolução, o controle dessa programação pode ser questionado, pois não haveria formas de monitoramento de uma evolução. Há um paradoxo nessa afirmativa, pois não há possibilidade de programar uma máquina (algo que prevê controle) para evoluir (algo que não pode ser controlado). No entanto, a robô apresenta traços de autonomia quando opta por se desligar. Em um diálogo com Billie, Spike diz:

\footnotetext{
- Os seres humanos são irracionais - disse eu. - Fazemos coisas por motivos inexistentes e depois procuramos encontrar uma boa explicação. Espero que você seja capaz de explicar isso a sua Central.

- Desconectei-me dela - disse Spike. - Resolvi viver como fora da lei. (WINTERSON, 2012, p. 242).
}

Questiona-se até que ponto uma robô que foi programada por um núcleo importante do governo teria a possibilidade pré-estabelecida de desligamento, ou seja, um falso livrearbítrio, pois se ela é controlada pelo governo, o controle total dela deveria ser relevante. Associa-se ela a pós-humanidade, pois a personagem carrega um dos princípios do póshumano, a autonomia do seu próprio corpo e mente, ou ainda, uma indução a autonomia. Outro ponto relevante é a relação direta da robô para com a espécie humana é que o nome, robô sapiens, carrega consigo um peso de semelhanças, seriam elas: a evolução, a capacidade de comunicação, traços de empatia e emoções e o corpo.

Em relação a comunicação da personagem-robô, observa-se que ela é bastante similar ao modo como as personagens transumanas se comunicam. Durante toda a narrativa, a robô sapiens não encontra dificuldade em estabelecer relações com os outros, exceto quando eles conversam sobre poesia. Spike diz: “[...] Conheço várias línguas e sou capaz de processar informações com a mesma rapidez de um computador ultrarrápido, mas não compreendi aquele único verso." (WINTERSON, 2012, p. 98). A robô, embora consiga ser eficiente em uma comunicação mais direta, quando desafiada para subjetividade de um poema acaba não conseguindo compreender as figuras de linguagem. Ainda que não haja como defini-la como uma pós-humana, com exceção da poesia, a personagem pode ser comparada as outras em 
relação a linguagem.

Além disso, a robô mantém traços fortes de empatia com as outras personagens, ela compreende as angustias delas e procura ajudá-las. Quando se pensa em um robô, não se espera tais reações, pois eles seriam funcionais, assim como todos os outros robôs da narrativa que inclusive possuem uma linguagem limitada e não conseguem estabelecer uma comunicação simples com a população de Orbus. Ela, no entanto, demonstra traços de interesse nas outras personagens, principalmente em Billie por quem está apaixonada. Ela diz para a narradora, aproximando-se muito das frases humanas: “[...] Nunca me esquecerei de você. Não posso me esquecer de você, nunca." (WINTERSON, 2012, p. 127). Há ainda a manifestação de emoções, algo muito similar aos humanos e transumanos, ou seja, a robô sapiens demonstra sentimentos o que poderia ser questionado a partir do momento que se compreende que ela seria uma robô programada para agir como os humanos. No entanto, se a evolução não pode ser controlada, a robô se torna transgressora, pois se apaixona por uma personagem humana e se envolve com personagens que não seriam as mais adequadas para ela. Tanto Billie, como as meninas da banda e as freiras (moradoras da cidade tecnológica) que viviam vidas que não estavam de acordo com o que o governo desejava manter, são personagens que desviam do padrão que os criadores de Spike (cientistas que trabalham para o governo de Orbus) imaginam como o ideal.

Por fim, observa-se o corpo de Spike, aspecto relevante da narrativa para compreender os traços pós-humanos que a robô carrega que seriam: a beleza extrema e o autocontrole de suas funções corporais. Mais do que qualquer outra personagem, a robô sapiens consegue controlar e adaptar o seu corpo para as situações necessárias, sem fazer desse corpo um objeto simplesmente funcional, pois carrega consigo espaço para o desejo, a beleza, como também a sobrevivência e, ainda que o relacionamento entre as espécies seja proibido, Spike atrai tanto Billie quanto o capitão Handsome, além dos outros tripulantes da primeira expedição para o planeta azul. Assim, ela possui tanto a beleza humana eterna como o domínio de suas funções. Hayles (1999) ao falar do corpo humano e da modificação desse corpo e comparar com a evolução no campo da robótica diz:

[c]omo tenho repetidamente argumentado, o ser humano é, antes de tudo, o ser incorporado, e as complexidades desta encarnação significam que a humanidade desdobra-se de maneiras muito diferentes das da inteligência incorporada em máquinas cibernéticas. [...] Este ponto cego é mais evidente, talvez, quando críticas literárias e culturais enfrentam os campos da biologia evolutiva. A partir do ponto de vista de um biólogo evolutivo, os seres humanos modernos, para todas as suas proezas tecnológicas, representam um piscar de olhos na história da vida, uma espécie distante muito recente para ter um impacto evolutivo significativo no comportamento e estruturas biológicas dos seres humanos. (HAYLES, 1999, p. $283-$ 
Comparar os avanços tecnológicos com a evolução da espécie é observar que há muitas diferenças. Todavia, embora os corpos e a tecnologia estejam juntos em muitos aspectos, ainda são espaços diferentes e evoluem de formas diferentes, o que humanamente sofreu evolução biológica e passou por seleção natural, agora é adaptado pelos humanos com instrumentos de trabalho que nos levam mais rapidamente a resultados. Não se está comparando os avanços da tecnologia com os da biologia, ou vice-versa, e sim, pensando no que a tecnologia pode proporcionar para os humanos. Nesse aspecto de tecnologia versus corpo, o corpo da robô sapiens seria a melhor representação desse corpo modificado, pois coloca, ainda que em uma realidade distante, a possibilidade da imortalidade e do autocontrole corporal para os habitantes de Orbus. A única forma de fazer com que a robô esqueça de tudo que ela sabe é desligando-a, ou seja, há uma capacidade mental, "[n]ao posso ler os seus dados - diz ela, lendo meus pensamentos em vez disso.” (WINTERSON, 2012, p. 44), mas também existe uma capacidade física de resistência as adversidades, um exemplo é quando ela começa a retirar partes do seu corpo para conseguir minimizar o uso de energia.

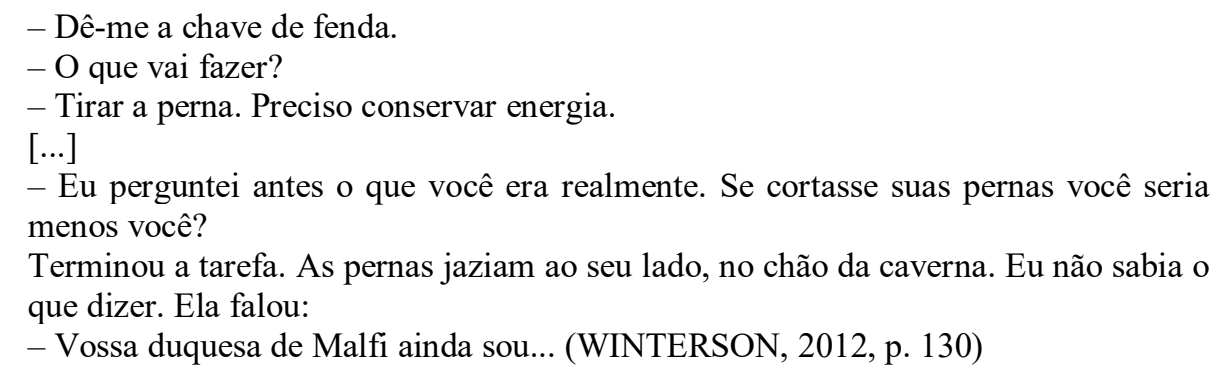

Mais do que a busca pela beleza, observando as condições climáticas de Orbus, uma maior resistência desse corpo poderia ser uma das salvações para essa civilização. Além de todos os padrões estéticos, haveria também uma maior funcionalidade desses corpos que além de belos também seriam perfeitamente funcionais. Ainda que existam algumas limitações entre o que se percebe com a robô e os transumanos, bem como alguns pré-julgamentos da sociedade, o estranhamento ocorre por aquilo que a tecnologia traz e que ainda não se tem acesso de fato, por isso nosso imaginário ainda se assusta quando se pensa no corpo mecânico, ou no uso de alta tecnologia para manutenção dos corpos.

\footnotetext{
${ }^{8}$ Do original: As I have repeatedly argued, human being is first of all embodied being, and the complexities of this embodiment mean that human awareness unfolds in ways very different from those of intelligence embodied in cybernetic machines. [...] This blind spot is most evident, perhaps, when literary and cultural critics confront the fields of evolutionary biology. From an evolutionary biologist's point of view, modem humans, for all their technological prowess, represent an eye blink in the history of life, a species far too recent to have significant evolutionary impact on human biological behaviors and structures.
} 
Noutros termos, as fantasias futuristas ensaiadas assim não devem ser tomadas pelo valor de face, mas pelo seu impacto ou sentido no presente. A reengenharia radical da condição humana por elas anunciada não depende apenas de recursos econômicos e vontade coletiva. O projeto também pressupõe um estágio de desenvolvimento do conhecimento científico e tecnológico que ainda está muito longe de ser alcançado, em que pese as proclamações em sentido contrário, como, por exemplo, as feitas pelos singularistas. (RÜDIGER, 2008, p. 203).

O que o humano pode criar através da tecnologia é o que assusta a humanidade, pois não se sabe até onde há, ou não, controle sobre esses recursos ainda incertos. No entanto, Rüdiger ainda diz que "recorrer a elas [tecnologias], concretamente, significa, antes de mais nada, engendrar publicidade e tentar mobilizar investimentos, significa operar no sentido de captar recursos, promover profissionais e criar um clima de opinião favorável” (RÜDIGER, 2008, p. 203). Na narrativa a robô é uma criação melhor do que as outras personagens, ela inclusive afirma que os robôs sapiens são mais evoluídos que os humanos.

- Sou um robô sapiens - disse Spike - e talvez nós sejamos o futuro do mundo, e não vocês.

$[\ldots]$

- Vocês estão se tornando obsoletos - disse Spike. Gerações sucessivas de humanos que estão perdendo suas habilidades mostram que vocês não são mais capazes de sobreviver por si próprios como faziam antigamente. Vocês dependem de técnicos e de robôs. (WINTERSON, 2012, p. 96, grifos da autora).

A manutenção estética dos corpos, que na narrativa é muito bem aceita socialmente, pode ser a porta de entrada para a modificação humana completa. O próprio processo de nãoenvelhecimento das personagens, embora focado na estética, só foi possível de ser realizado através de adaptações no DNA, de modo que já há uma alteração significativa nos corpos. Parece equivocado pensar que essas alterações devam se limitar ao estético como um modo de preservar uma essência humana que já está se desconstruindo a partir do momento que há uma constante interferência tecnológica nos nossos corpos.

De fato, o homem de que tanto se fala e em nome do qual se protesta não vale tanto,
não merece os sacrifícios que se vê naquele primeiro tipo de ficção. Nenhum de nós
é totalmente bom, puro ou inocente, sendo humano: conscientizar-se disso é o
primeiro passo para sermos algo melhor. Quem tem dó pelo homem revela que o
transcende moralmente. No entanto, é ingênuo, se não nota a infâmia que arrasta sua
existência. O homem é um misto de grandeza e miséria - e essa última prepondera
amplamente ao longo do processo civilizatório. (RÜDIGER, 2008, p. 206)

Os habitantes de Orbus estão em um limiar, ao passo que veem a morte diante dos seus olhos, pois apesar de belos seus corpos ainda são perecíveis. Eles são belos, mas seus corpos ainda são perecíveis, o que não seria o problema ou a destruição da robô sapiens que possui um autocontrole do seu corpo. O corpo da robô carrega os padrões estéticos sociais que são praticamente inatingíveis, ao mesmo tempo em que possui a vitalidade que um corpo 
transumano não tem, mas que com os avanços tecnológicos podem levá-los a chegarem a póshumanidade como indivíduos com maior capacidade de adaptação de seus corpos. Se os estudos acerca do transumanismo e pós-humanismo preveem a superação do próprio humano, acredita-se que uma das maiores superações que se poderia realizar seria chegar a vida eterna.

Verdade, nenhum método recomendado pela ciência - ou pela magia, a afirmação
ou a oração - nesse sentido - conseguiu até agora estender a vida humana além do
limite naturalmente evoluído de cerca de 120 anos. Mas o que mudou ultimamente é
que os geneticistas prolongaram a vida útil de pelo menos algumas criaturas vivas,
como os nematódeos, permitindo viver até sete vezes mais do que seus parentes não
modificados. Esta não é ainda a abolição da morte - mas parece muito com o
primeiro passo em direção a esse objetivo. (BRODERICK, 2013, p. 434, tradução
nossa) ${ }^{9}$.

Se por um lado a imortalidade humana ainda é um elemento ficcional, já há estudos científicos que almejam tal avanço. Se já se pensa sobre isso de maneira mais próxima da nossa realidade é porque também já se está pensando no pós-humanismo como algo possível, que permite nossa existência por mais tempo, ainda que não se saiba, assim como na narrativa, as possíveis consequências da vida eterna no âmbito social, político e, inclusive, geográfico. Sem descartar os estudos acerca da mente, o corpo ainda será mantido ou a sua representação estética. O corpo robotizado ainda terá características de corpo humano, mesmo com fios e metal em volta. Essa é também uma representação identitária do humano, assim como as características mentais, que nos colocam dentro dessa definição, ou seja, uma forma de ver o humano é enxergar o corpo humano tal como já conhecemos.

\begin{abstract}
Os avanços dramáticos em ciência e tecnologia nas últimas décadas culminaram em especulações generalizadas de que o próprio corpo humano, incluindo a sua complexa neurofisiologia, pode logo estar aberto ao redesenho consciente. Em algum momento, podemos ser capazes de fazer modificações extensas no DNA humano, nos tecidos corporais ou no funcionamento neurofisiológico, ou para unir nossos corpos com sofisticados dispositivos cibernéticos. As tecnologias emergentes podem nos dar, por exemplo, níveis mais elevados de inteligência [...]; aumento da força física, resistência e resistência à doença; longevidade prolongada; e talvez uma maior capacidade de empatia ou outros traços psicológicos valiosos. À medida que a tecnologia avança, alterando o corpo humano, pode nos conceder habilidades inteiramente novas. (BLACKFORD 2013, p. 441-422, tradução nossa) ${ }^{10}$.
\end{abstract}

\footnotetext{
${ }^{9}$ Do original: True, no method recommended by science - or by magic, affirmation, or prayer, for that matter has managed so far to extend human life beyond the naturally evolved limit of about 120 years. But what has changed lately is that geneticists have extended the lifespan of at least some living creatures, such as nematode worms, allowing them to live as much as seven times longer than their unmodified kin. This is not yet the abolition of death - but it looks very much like the first step toward that goal.

${ }^{10}$ Do original: Dramatic advances in science and technology over the past few decades have culminated in widespread speculation that the human body itself, including its complex neurophysiology, may soon be open to conscious redesign. At some point, we may be able to make extensive modifications to human DNA, body tissues, or neurophysiological functioning, or to merge our bodies with sophisticated cybernetic devices. Emerging technologies may give us, for example, higher levels of intelligence [...]; increased physical strength, stamina,
}

Anu. Lit., Florianópolis, v. 23, n. 1, p. 154-173, 2018. ISSNe 2175-7917 
Os avanços tecnológicos estão mais à frente do que é disponibilizado para o nosso uso atualmente. Há estudos que visam a possibilidade do transplante cerebral para outros corpos, ou ainda que procuram formas de salvar a mente humana. Há pesquisas que propõem buscar a imortalidade do humano e que colocam o corpo como um primeiro espaço para a intervenção, como a criogenia. Mesmo não havendo nenhuma certeza o corpo é mantido e parece ser importante para os indivíduos que procuram por esse serviço manterem os seus corpos preservados. $\mathrm{O}$ mesmo acontece na narrativa, não há em nenhum momento citações que nos remetam a imortalidade; no entanto, há uma constante manutenção dos corpos, o que leva a crer que ainda que se tenha um mercado que induz os habitantes a isso, há também uma preocupação com a durabilidade desses corpos.

\section{Conclusão}

A partir dessas reflexões observa-se que o corpo tem bastante relevância para os estudos de transumanismo e pós-humanismo que são também estudos identificados dentro da narrativa de Jeanette Winterson, pois coloca em evidência aspectos das transformações do corpo através de avanços tecnológicos que visam padrões estéticos. Tais padrões já são presentes na nossa sociedade e a narrativa reflete as possíveis consequências para tantas modificações, inclusive apontando para uma mudança regressiva de relações sociais e redefinições de aspectos éticos que devem ser levados em conta diante de transformações que assemelham indivíduos.

O corpo parece ganhar mais espaço do que se pode imaginar na compreensão de humano, transumano e pós-humano. Ao mesmo tempo que é evidenciado por tantas adaptações (ganha relevância social, representação de um espaço que revela traços de personalidade), perde ao procurar a diferença, pois encontra a similaridade dos padrões estéticos. A ideia de rejuvenescimento e beleza, na narrativa, nada mais é do que uma padronização de um ideal de corpo e aparência que coloca os habitantes de Orbus como produtos de um mercado estético, em que os corpos deixam de ser livres, pois só são aceitos dentro de um 'esquema' de boa saúde que nada mais é do que uma aparência, mas não uma realidade desses corpos, bem como desses transumanos que acabam ficando mentalmente desestabilizados e alienados em relação a outros aspectos sociais que a narrativa apresenta.

O que está para além do corpo biológico também é associado ao corpo de humanos para ganhar maior força, respeito e aceitação social, basta observarmos a diferença de relação

and resistance to disease; extended longevity; and perhaps an enhanced capacity for empathy or other valued psychological traits. As technology goes inwards, altering the human body, it may grant us entirely new abilities.

Anu. Lit., Florianópolis, v. 23, n. 1, p. 154-173, 2018. ISSNe 2175-7917 
entre a robô sapiens com os habitantes de Orbus e os outros robôs, puras máquinas com funcionalidades restritas. A forma física do corpo, ajustado e adequado a padronização estética é também o que permitiu que a robô sapiens fosse compreendida como algo além de uma mera máquina funcional. Ainda que não haja uma perspectiva de um pós-humano, é possível pensarmos que a robô sapiens seria um possível modelo para a compreensão de um corpo pós-humano, em que haveria um autocontrole das capacidades físicas.

Conclui-se que a narrativa permite a abertura para discussões do corpo como um falso domínio dos desejos, pois mostra que a supremacia da mídia e do capitalismo é o que permite que tais padrões avancem e ganhem forma, a medida em que só se é aceito se tais padrões forem preenchidos e colocados como um plano de fundo das alterações dos humanos. O corpo torna-se o produto da estética o que gera conflitos individuais e também sociais. Ao que tudo indica, os avanços tecnológicos positivos para o transumanismo e o pós-humanismo estão apenas mascarando ideais capitalistas para tornar a sociedade cada vez mais alienada, ao menos em Deuses de Pedra.

\section{Referências}

BLACKFORD, Russel. The Great Transition: Ideas and Anxieties. In: MORE, Max; VITAMORE, Natasha. The transhumanist reader: classical and contemporary essays on the science, technology, and philosophy of the human future. United Kingdom: Wiley-Blackwell, 2013, p. 421-429.

BRODERICK, Damien. Trans and Post. In: MORE, Max; VITA-MORE, Natasha. The transhumanist reader: classical and contemporary essays on the science, technology, and philosophy of the human future. United Kingdom: Wiley-Blackwell, 2013, p. 430-437.

HAYLES, N. Katherine. Conclusion: What Does It Mean to Be Posthuman? In: HAYLES, N. Katherine. How we became posthuman: virtual bodies in cybernetics, literature, and informatics. Chicago: University of Chicago, 1999, p. 283-292.

HILÁRIO, Leomir Cardoso. Teoria Crítica e Literatura: a distopia como ferramenta de análise radical da modernidade. Anuário de Literatura, Florianópolis, v.18, n. 2, p. 201-215, 2013.

LIMA, Marisa Mello de. Do corpo sob o olhar de Bourdieu ao corpo contemporâneo. In: Seminário Nacional Corpo e Cultura, 4, 2013, Goiânia. Anais... Goiânia: UFG, 2013, p. 1-17.

MARKS DE MARQUES, Eduardo. Da centralidade política à centralidade do corpo transumano: movimentos da terceira virada distópica na literatura. Anuário de Literatura, Florianópolis, v. 19, n. 1, p. 10-29, 2014.

MARKS DE MARQUES, Eduardo; PEREIRA, Anderson Martins. A justaposição do póshumano e do transumano no gênero distopia: uma análise das trilogias Divergente e A $5^{\text {a }}$ Onda. Ilha do Desterro, Florianópolis, v. 70, p. 119-127, 2017. 
MAZLISH, Bruce. Humanities, humanitarianism, and the human. In: MAZLISH, Bruce. The idea of humanity in a global era. United States: Palgrave Macmillan, 2009, p. 61-76.

MORE, Max; VITA-MORE, Natasha. Part 1: Roots and Core Themes. In: MORE, Max; VITA-MORE, Natasha. The transhumanist reader: classical and contemporary essays on the science, technology, and philosophy of the human future. United Kingdom: Wiley-Blackwell, 2013, p. 01-02.

NEGRIM, Llewellyn. Cosmetic Surgery and the Eclipse of Identity. In. NEGRIM, Llewellyn. Appearance and Identity: Fashioning the Body in Postmodernity. United States: Palgrave Macmillan, 2008, p. 75-96.

RÜDIGER, Francisco. Cibercultura e Pós-humanismo: exercícios de arqueologia e criticismo. Porto Alegre: EDIPUC, 2008.

TRINCA, Tatiane. O corpo-imagem na “cultura do consumo”: uma análise histórico-social sobre a supremacia da aparência no capitalismo avançado, 2008, 154 f. Dissertação (Mestrado em Ciências Sociais), Universidade Estadual Paulista, Marília, 2008.

WINTERSON, Jeanette. Deuses de Pedra. Rio de Janeiro: Record, 2012.

Transhuman and Post-human in The Stone Gods: The validation of the standardized body in Jeanette Winterson's dystopia

Abstract: The Stone Gods (2012), written by Jeanette Winterson, presents a dystopian narrative space of the past, where the inhabitants of the planet Orbus, practically destroyed by human interventions, live for the genetic transformations and aesthetic improvements of their beautiful and young bodies. At the same time, there is a technological advance in the development of robots, being the most representative the sapiens robot, which is extremely intelligent and beautiful and with physical human characteristics. Thus, there are bodies distinct materially, however, visually similar from an ideal standard of beauty that encourages the change of bodies as a way of social adaptation. In this paper, we will analyze the relationship between body and technology, and what is the implication of those discussions for the studies of transhumanism and post-humanism from the altered bodies of the characters and the consequences of these alterations when thinking about the creation of an ideal body that promotes an erroneous idea of perfect health through technological interference.

Keywords: Body. Technology. Transhuman. Post-human.

Recebido em: 29/01/2018

Aceito em: 05/02/2018

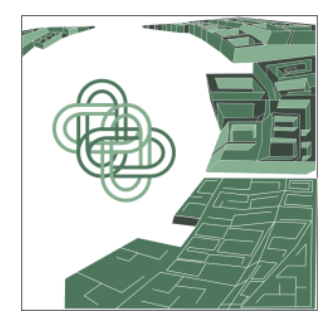

